DOI: 10.1515/ausfm-2016-0018

\title{
Subjects and Objects of the Embodied Gaze: Abbas Kiarostami and the Real of the Individual Perspective
}

\author{
Zsolt Gyenge \\ Moholy-Nagy University of Art and Design Budapest (Hungary) \\ E-mail: zsengezsolt@yahoo.com
}

\begin{abstract}
It is widely accepted that Abbas Kiarostami's cinema revolves around the representation of the gaze. Many critics argue that he should be considered a late modernist who repeats the self-reflexive gestures of modernist European cinema decades after they were first introduced. The present paper will contradict this assertion by investigating the problematic of the Kiarostamian gaze and analyzing the perceptual side of the act of looking. I will argue that instead of focusing on the gaze of the spectator directed towards the filmic image, he exposes a gaze that is fully integrated into the reality to be captured on film. The second part of the paper will explain this by linking the concept of gaze to the Lacanian concept of the order of the Real. Finally, I will contextualize all this by discussing the Iranian director's position between Eastern and Western traditions of representation.
\end{abstract}

Keywords: Abbas Kiarostami, gaze, Jacques Lacan, perception, the Real.

Since Jean-Luc Nancy's famous book on Kiarostami entitled L'évidence du film (Nancy 2001), the gaze of the Kiarostamian camera has become the center of most analysis focusing on the Iranian filmmaker. Several facts, such as that his miseen-abyme is operated not only within a film, but through multiple works; that in some cases a film director is the main character of the movie; that a film crew, sometimes Kiarostami himself, is present in the diegesis; and finally, the fact that he shoots fictions and documentaries alike make obvious that the problem of the gaze oriented towards the reality to be represented has to be discussed. As Frédéric Sabouraud explains: "[i]n a certain way everything is gaze in Kiarostami, because his system [...] is based not only on the perception of reality through the vision that has the character of it, but also on the vision of the spectator facing the images" $(2010,75)$. The gaze is central to the Iranian director's work, which is 
also confirmed in his 2008 film, Shirin (Nancy's book appeared years before this film). Shirin constitutes an extreme moment in Kiarostami's oeuvre as it presents the pure gaze, the embodied gaze without object, ${ }^{1}$ focusing on the act of looking as an isolated event (Grønstad 2013, 29).

The gaze is a complex issue in Kiarostami's cinema, largely because it is a governing principle that operates on at least two levels. Firstly, some of his films are linked together by a number of references, this is the case, most obviously, of the Koker trilogy, where the second and third films invoke the previous ones. $^{2}$ Together with the many incidents (Sabouraud's term) that take place in Kiarostami's films, and which destroy the illusion of fictional representation, ${ }^{3}$ this approach should be considered as a self-reflexive gesture intended to enhance the viewer's consciousness of the act of viewing. When analysing Kiarostami's cinema, one might ask: if it is based on this self-reflexive approach, should he not simply be considered a late modernist (in the same way as Haneke), who is merely emphasizing the overwhelming presence of the medium decades after this idea became popular in arthouse cinema? In what follows, my argument will prove that this is not the case, especially due to a second level of representation of the gaze. I agree with Nancy, who states that "[Kiarostami] is not interested in the film about the film or in the film, he is not investigating the mise-en-abyme" (2001, 27). Though Kiarostami frequently reminds us of the fact that we are watching a

1 Shirin (2008) is a ninety-minute experimental film in which we only see close-ups of faces watching and reacting to a cinema screen during the projection of a traditional (though nonexistent) Iranian film. We do not get to see a single image of the film within the film, we are forced to deduct the story based on the sounds and dialogues, as well as the emotional reactions of the viewers.

2 The Koker trilogy is one of the most sophisticated examples of this kind of quoting a film within a film. The second movie, entitled Life, and Nothing More... (1992) presents a film director who revisits the region where his previous film was shot, and where an earthquake took place between the two shootings. Obvious references to the title, poster and protagonist of the first film are made during the quest. In the third film of the trilogy (Through the Olive Trees, 1994) we watch the way in which the second film was made, how the casting took place in the village, what conflicts arose between the amateur actors, etc. Furthermore, this third film begins with a short monologue by the actor playing the director of the second film, who declares that, of course, he is not the real director of Life, and Nothing More..., just an actor. This is made very clear at a certain point in the film, when the characters pass the crew of the second film, who are shooting a scene, and where, for a very brief moment we can glimpse Kiarostami himself, who - according to the diegetic world of the third film - should not be there.

3 Sabouraud calls them incidents because they are disguised as small, unintentional glitches. Think of the scene in Life, and Nothing More... where Mr. Ruhi tells the child that, in fact, he was made to look older in the film, and that the house that he presents as being his home is actually not his. The same happens in Close-Up (1990) when, by the end of the film, the real Makhmalbaf finally meets the protagonist: the sound equipment apparently breaks down and we are unable to hear their dialogue. 
film, what is much more important is that he places the gaze at the center of the represented reality. Kiarostami's cinema is not about the constructed nature of cinematic representation, but about the constructed nature of reality itself.

This is best shown by the fact that we can grasp another level of the representation of the gaze which is equally important in Kiarostami's films, and which Sabouraud only partially mentioned when discussing a character's vision of reality (I refer the reader back to the quote on the previous page). It is important to understand that Kiarostami not only speaks about the characters' vision but that his films are organized to make visible and to expose a gaze that is capable of constituting, of forming the world itself. Thus, instead of the multiplicity of interpretations, it is the formative power of the gaze that comes to the foreground. Through the inclusion of the gaze of the camera and the director's gaze in both the narrative and visual composition of his films, and the combination of the formal aspects of documentary and fiction, Kiarostami creates a representation of reality that is able to grasp this invisible, yet so essential side of reality that is related to the formative power of the web of gazes within it.

Most scholarship focusing on Kiarostami's approach to reality and the mediation between documentary and fiction is convinced that this attitude reveals a certain disbelief in the representational capacities of film in general, and of documentary in special. On this point, Frédéric Sabouraud writes: "[t]his is a strange fiction, that seems not to believe in the documentary take [...], but at the same time gives the impression to distrust like hell a fiction [...] that is risking to destroy the essence, the truth of the scene" $(2010,36)$. In my view, it is not disbelief in the medium itself that we experience here, as Kiarostami is a devoted fan of cinema. Rather, we are facing a different understanding of reality - an understanding that considers the gaze to be not only part of the medium, but fully integrated into the reality that is being captured. In this sense, the gaze is not only the subject, but also the object of perception, which is exactly how Merleau-Ponty conceived it, and to some extent, Lacan and Sartre as well. ${ }^{4}$ At the heart of Merleau-Ponty's notion of perception is that "my body simultaneously sees and is seen," so my body is part of the world, of the things that it observes, and this results in a primordial

4 At the heart of Merleau-Ponty's notion of perception is the idea that my body simultaneously sees and is seen, so my body is in every sense part of the world, of the things that it observes. And thus, the act of seeing originates from the world, the medium of things. This is what phenomenology calls chiasm, chiasmatic structure: that who perceives is in the very same moment perceivable, exposed to the perception of the world he observes. Chiasm is about the interconnected nature of the seeing subject and the seen object. And this results - according to him - in a primordial subjectivity: we simply cannot transcend our embodied, material and irreducible relation with the world (Merleau-Ponty 2002 and Merleau-Ponty 1964). 
subjectivity: we simply cannot transcend our embodied, material and irreducible relation with the world. Thus, the act of seeing originates from the world, it is what phenomenology calls chiasm (Merleau-Ponty 2002 and Merleau-Ponty 1964).

In the Phenomenology of Perception Merleau-Ponty explains the enworlded nature of perception - and thus the constitutive characteristic of the gaze through the notion of depth (profondeur). According to him, the most important aspect of the perception of space is orientation: "[g]enerally speaking, our perception would not comprise either outlines, figures, backgrounds or objects, and would consequently not be perception of anything, or indeed exist at all, if the subject of perception were not this gaze which takes a grip upon things only in so far as they have a general direction; and this general direction in space is not a contingent characteristic of the object, it is the means whereby I recognize it and am conscious of it as of an object" (Merleau-Ponty 2002, 295). Depth (of space) is a crucial dimension, in particular because it immediately reveals the relationship between the subject and the thing: "the vertical and the horizontal, the near and the far" has sense only from the perspective of our relation to the world (Merleau-Ponty 2002, 310-311).

Cinema is probably the best medium to grasp the constitutive gaze - a notion of the gaze that takes into consideration not only the subjective perspective of the filmmaker, but one which is also able to identify a gaze that becomes the object of the cinematic gaze itself. "Cinema presents - that is to say, shares (communicates) - the intensity of a look upon a world of which it is itself part and parcel [...]. It is part of it precisely in the sense that it had contributed to its structure as it is now: as a world where looking at what is real is resolutely substituting for every kind of visionary seeing, foreseeing, and clairvoyant gazing." (Nancy 2001, 20.) From this perspective, it is vision that generates the world - a vision that is entirely part of the world it observes. As Sabouraud points out (2010, 82), this can be unmistakably observed in Kiarostami's so-called car films ${ }^{5}$ (especially Taste of Cherry and Ten), where the car is both the cinematic apparatus for recording reality and the element whose observational presence triggers the action. This understanding of the gaze is made evident in almost all of his films through the characters' relation to their surrounding world. ${ }^{6}$ Sabouraud also emphasizes

$5 \quad$ A term used by critics and scholars to describe those films of Kiarostami in which action is built upon a main character driving around in a car. (Sabouraud 2010, 81-83.)

6 A few examples from Kiarostami's oeuvre: in Close-up (1990), the filmmaker is part of the events he follows to the extent that we are not able to watch the scenes where he is not allowed; it is the recording equipment, the cinematic apparatus that is first shown at the beginning of the documentary Homework (1989); it is the semi-fictitious film director we follow throughout Life 
(2010, 81) that although they are characterized by their gaze upon the world, these characters should not to be taken as voyeurs. As I see it, these protagonists are not exactly voyeurs because they are very visibly integrated into the world that surrounds them. Their gaze is more than just outer observation: it effectively changes reality. The characters are genuinely part of the world through their constitutive gaze, and in this way in Kiarostami's cinema it is vision and gaze that take over the role of action. The gaze made visible through cinematic representation constitutes the visible world.

In his early feature Where Is the Friend's Home? (1987) it is surprising to see how the mother is not able to leave behind the rigid perspective she has on the world. Ahmed tells her many times that he has to take back the notebook of his friend that remained accidentally in his bag, but she does not listen to him, she thinks that the child (as children always do) just wants to play and thus escape the responsibility of homework. What is interesting here is that the mother does not think that her boy is lying, she just does not listen to him because her attitude towards the world, her perspective is governed by patterns or (even unwritten) laws. The same is true in the scene with Ahmed's grandfather, who is not interested at all in Ahmed's reasons, he just wants to once again put into practice a hierarchical pedagogical practice used for generations, a practice that also defines his own world-view. This is the reason why he sends the kid to bring him the cigarettes that - as he is well aware - are hidden right in his pocket.

Probably the best or most obvious example of the constitutive gaze of a character can be found in Kiarostami's Certified Copy (2010). The owner of the café where the two main characters (who most probably have met just a few hours earlier) ${ }^{7}$ sit down to have a discussion seemingly mistakes them for husband and wife, and afterwards they start acting accordingly. It is the individual perspective, the gaze of the old lady that changes reality in such a way that, ultimately, we are also uncertain about the true nature of their relationship. With this quite straightforward turn Kiarostami makes his viewers aware that the major issue for him in this respect is neither the gaze of the spectator watching the filmic image

and Nothing More..., who explores a reality (the present situation of the actors of the previous film) that would not exist without him; the presence of the reporter and his crew in The Wind Will Carry Us is by itself distorting the reality it tries to capture, so much so that the dying old woman lives much longer than she has been expected almost only to defy the curious gaze of the camera.

7 There has been much critical and scholarly dispute on the actual role and relationship of the two protagonists. Based on the child's referring to James as a stranger ("Ce James," this James), I would agree with Simon Levesque that though there is a clear "referential jamming" here, it is more plausible that the two are acting out as actors playing and taking seriously a spontaneous fiction (Levesque 2013, 9-10). 
nor the gaze of the medium distorting reality, but those gazes that operate - often without being observed - within the reality to be grasped.

\section{Kiarostami and the Lacanian Real}

It is Laura Mulvey who first linked Kiarostami's cinema to the Lacanian concept of the Real in her book Death 24x a Second (Mulvey 2006, 123-143). Mulvey argues that the tragic earthquake which destroyed the village and region where the first film of the Koker trilogy was shot is left intentionally unseen, unrepresented by Kiarostami in the following two films. The lack of any kind of re-enactment creates a situation where the actuality of the invisible yet traumatic event is unquestionable - exactly in the same manner as Lacan describes the order of the always hidden Real that is behind or beneath any phenomenal appearance accessible to direct experience (Mulvey 2006, 128).

Interpreting Kiarostami's cinema using the Lacanian concept of the Real helps us to understand several motifs of the oeuvre. Arguably, the clearest parallel to the (lack of) representation of the earthquake in the Koker trilogy is found in The Wind Will Carry Us (1999), where we never get to see the old lady who is expected to die so that the crew can film the famous burial ceremony. Her invisible yet very important presence is emphasized by the struggle of the protagonist, who checks her situation every day by taking a distant look at her house.

While acknowledging the theoretical usefulness of Mulvey's approach, I will employ the Lacanian concept in a different way since, in my view, it is the exposed actuality of the unseen (yet always present) gaze that should be described as the Real. The idea was already formulated, although not fully elaborated by Jean-Luc Nancy: "[t]he reality of images is the access to the real itself [...]. Before the filmmaker's gaze that we must fit, there is no room for reflexivity or for speculation on looking and images. We are dealing neither with formalistic (let us say, tentatively 'symbolic') nor with narcissistic (let us say 'imaginary') vision. We are not dealing with sightseeing or voyeuristic, fantasizing or hallucinating, ideative or intuitive-but solely with looking: it is a matter of opening the seeing to something real, toward which the look carries itself and which, in turn, the look allows to be carried back to itself" (2001, 16-18). It is the lack of reflexivity and speculation emphasized by Nancy that makes this view important for us, because it brings forward the hidden characteristic of what I have called the constitutive gaze.

As Todd McGowan points out, Lacan has had a huge influence on film theory because his approach became the starting point for an ideological analysis of the 
gaze considered to be the function of the imaginary that dupes us: the gaze is the misguided look of the spectator (McGowan 2007, 4). But according to McGowan, so-called early Lacanian film theory (for example, Mulvey, Baudry, Comolli, and others) misunderstood Lacan, so he suggests to go back to the original Lacanian concepts themselves. He argues that we should not work on the subjective gaze of the spectator of the filmic image (which was the starting point for all analysis of ideological representation in cinema). Instead, we should consider the gaze as Object. "In the years after the essay on the mirror-stage, Lacan comes to conceive the gaze as something that the subject (or spectator) encounters in the object (or the film itself), it becomes an objective, rather than a subjective gaze. [...] Understood in Lacan's own terms, the gaze is not the spectator's external view of the filmic image, but the mode in which the spectator is accounted for within the film itself." (McGowan 2007, 5-7.) The gaze is a blank point, "it is the point at which the spectator is obliquely included in the film" (McGowan 2007, 8).

The inclusion of the gaze in the image destroys the invisibility of the spectator, which was considered the crucial element of the voyeuristic experience of cinema. If in the (filmic) image the gaze is present as a stain (as Lacan puts it), we arrive to the idea of the reversibility of seeing, to the chiasmatic nature of perception, as described by Merleau-Ponty. As the French phenomenologist explains in Le visible et l'invisible, we are always subjects and objects of vision; we are able to perceive and to be perceived at the same time. This phenomenon of the perceptual experience of seeing and being exposed to a gaze is described by Lacan in the terms of a split between the Eye and the Gaze (1978, 67-78).

Lacan does not agree with Sartre's phenomenological description of the gaze (Lacan 1978, 84), who tackles the same issue from a different perspective as he discusses the gaze in relation to the existence of Others. ${ }^{8}$ The very definition of the Other in his view is that it is capable of seeing me: "being-seen-by-theOther' is the truth of 'seeing-the-Other"' (Sartre 1978, 257). And when it comes to the issue of the gaze, for Sartre, the most important aspect is that although we relate it to an eye, the two cannot be perceived simultaneously. "If I apprehend the look, I cease to perceive the eyes; they are there, they remain in the field of my perception as pure presentations, but I do not make any use of them [...]. We cannot perceive the world and at the same time apprehend a look fastened upon us; it must be either one or the other. This is because to perceive is to look at, and to apprehend a look is not to apprehend a look-as-object in the world (unless

8 See the chapter The Existence of Others (Sartre 1978, 221-302), especially section IV: The Look (Sartre 1978, 252-302). 
the look is not directed upon us); it is to be conscious of being looked at." (Sartre 1978, 258-259.) This approach is important for cinema (and for the analysis of Kiarostami) for at least two reasons. Firstly, it makes clear that although gaze has been analysed in so many different ways in film theory, representing the gaze as object in cinema is not a simple task: the image of a face, or of an eye on its own will not suffice. In order to be able to show it, Kiarostami has developed a complex strategy - which will be presented in the last section of this paper. Secondly, it emphasizes the chiasmatic structure of perception and vision as described by Merleau-Ponty from yet another perspective.

On this basis, I suggest considering the gaze in Kiarostami's oeuvre as the unseen, hidden and traumatic Real that defines everything despite its apparent absence. In his famous Seminar XI, Lacan declared: "[i]n our relation to things, in so far as this relation is constituted by the way of vision, and ordered in the figures of representation, something slips, passes, is transmitted, from stage to stage, and is always to some degree eluded in it - that is what we call the gaze" (Lacan 1978, 73). This is true not only for the gaze between characters (which will be elaborated later on), but also for the invisible real presence of the cinematic apparatus, that is, the gaze, or the act of perception itself. In Kiarostami's view the cinematic apparatus is not only a medium that defines the image the spectator is able to perceive, but is also a gaze that is part of the world it represents. It is quite interesting to observe the difference between the way in which the director makes his point at the beginning of his career, and then some twenty years later. In the documentary, Homework (1989) the interviews begin with a shot of the set, where beside the interviewee and the director himself we can clearly see the camera and the DOP, the apparatus that will later clearly influence some of the students during their confessions about sensitive issues. [Fig. 1.] In 2010, in his first European film (Certified Copy), the cinematic apparatus (the camera object) is still present but in a much more subtle, almost invisible way, similar to Lacan's imperceptible Real. After having shown several shots of the protagonists staring directly into a mirror which is subsequently replaced by the camera, in the scene that takes place in the restaurant, in which James is absent, Juliette Binoche fixes her earrings and hair while staring into the camera in a room where there is no mirror at all [Fig. 2]. In this situation one can find no other convincing explanation than that she used the lens of the unseen yet always present camera as mirror. In this way, the camera, and through it the gaze itself, becomes part of the diegesis, it is observing and representing. I consider that this exemplary moment bears a symbolic value for Kiarostami's cinema as a whole by clearly 
showing the director's deep conviction regarding the actuality of the invisible gaze that affects every moment of life.

\section{Eastern and Western Traditions of Representation ${ }^{9}$}

In what follows, I will discuss how the issues tackled above should be interpreted within the context of Islamic rules of representation. It is remarkable that the gaze and observation is in the focus of the work of a visual artist who lived and worked for decades in a country that has severe rules limiting representation; and it is also quite surprising that - contrary to some of his colleagues - he has never been convicted for breaking these rules. This is relevant to the topic of this paper because one of the most problematic matters in Islamic culture is related precisely to the gaze. As Sussan Shams points out in her book on Kiarostami, in Eastern and especially Islamic cultures, the veil should be interpreted as a metaphor for the blocking of the scrutinizing gaze. After describing the representational conventions of Persian painting and miniatures, she argues that even traditional houses (having high walls and windows which only open onto the inner court) and the structure of towns were designed in order to block the foreigner's gaze, to stop the public sphere from invading the private (Shams 2011, 49-58). She writes: "the position of Islamic societies towards the 'gaze' is special in the sense that it associates it with perversion and voyeurism" (Shams 2011, 57). In this way when it comes to visual representations "we can say that in this aesthetic what is questioned is less the represented object itself, and much more the 'gaze' directed towards this object, towards the visible" (Shams 2011, 58). This is the reason why it is so remarkable that although Kiarostami lived in Iran, and was also a documentary filmmaker, he never presented the specificities of the provincial Iran (The Wind Will Carry Us) or of the damaged region of Koker (Koker trilogy) in detail. Instead, in all these films he focuses on the gaze of a stranger arriving there to exploit the tragic events through representation. It is instructive to compare this situation to the case of Michelangelo Antonioni's documentary on China, as related by Susan Sontag. According to her, Chung Kuo - Cina (1973) caused serious resentment amongst Chinese audiences not because of what it showed, but due to the unconventional camera angles and compositions employed by the Italian director and his crew. Apparently, the problem was rooted in the fact that

9 Even though this formulation and dichotomy is oversimplifying, it is needed for pointing out some characteristics of Kiarostami's cinema. The introduction of the broader cultural context of the so-called Eastern and Western tradition of representation helps to make clear the crucial role of the constitutive gaze in his films. 
it was not the object that determined the image, but the position of the observer, the gaze directed towards it (Sontag 2005, 132-137).

This is the reason why I find Shams's conclusion so surprising: after presenting a detailed analysis on the characteristics of Islamic visual representation, she argues that Kiarostami is in fact translating the logic of Persian paintings and miniatures into the language of cinema (Shams 2011, 101). In my view, Kiarostami is doing exactly the opposite: he is in fact putting into practice a so called Western understanding of representation, and he does so in a cinema dealing with a society which believes in quite different representational rules and conventions. This contradiction is one of the main sources of tension in almost all of his films. And this is precisely why we should consider the possibility that with Certified Copy, shot in Florence, Kiarostami did not wander into foreign territory, but, in fact, just came home. In the city where the rules of Renaissance perspective were born, the idea that the (optical) position of the viewer defines the limits of his vision is the natural understanding of perception and visual representation. In Certified Copy several scenes are constructed thematically and visually in such a way that they reflect the overwhelming presence of the individual perspectival gaze. For example, there is the scene where the two protagonists, simply because of their point of view, mistake the angry phone conversation of a passer-by for a marital quarrel.

Shams explains how the painters of the Muslim world - in accordance with the conventions of the Islam - abandoned the representation of the depth of space, and how they chose two-dimensional rendition. They used vertical instead of horizontal composition, and thus, all that was presented as being behind in Western images was presented by them as being above (Shams 2011, 106-108). In miniatures we also find a vertical arrangement, where the painter "carves out" the space in the image without resorting to the perspectival illusion of the depth of space (Shams 2011, 45). The conclusion that the same compositional logic can be observed in Kiarostami's cinema is surprising because it is quite obviously the opposite that takes place: as several scholars writing on Kiarostami (including Shams herself) point out, it is striking how verticality is almost completely missing from his compositions. In this regard, Alain Bergala's descriptions are really enlightening. He describes in detail how already in Where is the Friends Home? or in Life, and Nothing More... we only see the first floor of two-story buildings and everything else is only present as the space outside the frame (Bergala 2004, 78). It is clear that Kiarostami is open to accept artificial cinematic situations just to avoid vertical compositions. 
Hajnal Király also argues that Western reception is overemphasizing the Western roots of Kiarostami's cinema. Her argument is built on the fact that selfreflection in the Iranian director's films is completely different from what we are used to in Western art cinema. "Kiarostami's approach to cinema is completely different: he is not conceiving cinema as art, but a medium, a 'third party' ready for intervention, a rather poetic tool revealing, through gaps and lies, a sociocultural reality and truth." (Király 2010, 141.) She considers the observable self-reflexivity in Kiarostami's films to have nothing to do with the playful-narcissistic selfreflexivity of Western art, instead, she claims it is much closer to the ornamental and symbolic iconography of Persian miniatures. I agree with Király that this is a completely different self-reflexivity, but I do not think she takes this line of thought far enough. It is very true that the Kiarostamian gaze upon the world does not simply want to show itself in a narcissistic way, but what is really important here is that this forever individual gaze is an intrinsic part of the observed world. Thus, a representation of the world without this worldly, human gaze is simply inconceivable - and this idea is far away from the logic of Persian miniatures, and, more generally, from Islamic understanding of visual representation.

The depiction of viewpoints and gazes becomes very sophisticated in the third film of the Koker trilogy. Here, due to the fact that everything is watched from somewhere, the shots and camera movements are able to make the importance of the gaze visible on their own. Alain Bergala makes this point in his convincing analysis of a scene from Through the Olive Trees (Bergala 2004, 72-74), where the young Hossein tells the (fictional) director the story of his unsuccessful marriage proposals. These proposals were at first addressed to the parents of the girl, but following their death in the earthquake he turned to the grandmother, who was then taking care of Tahereh. But also the grandmother refused him - not because she agreed with the arguments of the deceased parents, who considered the uneducated young man unworthy of their daughter - but simply because she respected the decision of the dead. At a certain point during the discussion there is a flashback which shows the moment when Hossein once again approaches Tahereh and her grandmother in the cemetery. The position and movements of the camera clearly suggest a POV shot, though we are not aware of the person watching all this. Hossein is the focal point of the image, but after a few moments both Tahereh and her grandmother appear in the scene and then leave the place, while the camera stays put - which clearly shows that none of them can be the observing subject. It takes a few seconds until we realize that the camera followed the scene from the point of view of "the gaze of the tombstone" of the 
dead parents, conveying thus their attitude towards Hossein. [Fig. 3.] In his films and interviews, Kiarostami refers indirectly, or sometimes directly, to the enormous power the habits and laws passed on by previous generations have over the Iranian society as these are considered unquestionable by the living. Alain Bergala presents the Law as a sort of unchanged tradition passed from generation to generation, without critical reflection because the law is considered a form of an impersonal truth and thus it is out of reach for the individual (Bergala 2004, 22). Through the use of the personalized, enworlded optical viewpoint of Western perspectival images, Kiarostami demonstrates the all-round presence of the gaze. And, more significantly, by doing this in Through the Olive Trees, he manages to expose the invisible Real, the actuality of the gaze, arguing thus in a very subtle manner that these so-called laws handed down by former generations should be understood as mere individual perspectives.

In conclusion, I believe that Kiarostami developed a subversive position within Iranian cinema, not due to the content of his films (which is why he has never been banned by Iranian authorities, unlike his former collaborator Jafar Panahi), but due to their form. Kiarostami does not show things, objects or situations that are not allowed to be screened, instead, he shows them in a way unfamiliar in Iran. The harsh social realities presented by Panahi are only the consequences of a worldview that denies the legitimacy of the individual gaze, a worldview that is overridden by Kiarostami's cinema. Only the impersonal law, the rigid, alienated, conventionalized tradition of a patriarchal and hierarchical social system is the one that pretends to lack a gaze - and so do the images created within such a tradition. Kiarostami does not accept the denial of the raison d'être of the individual gaze because he thinks it is exactly the reason why Iranians (and especially women) cannot make life choices based on their personal needs and desires. The fact that he puts the individual gaze directed upon this reality in the center of his films and not the social realities of the country is not just a simple play with formal elements of visual and cinematic expression, it is the central and most subversive element of his art. 


\section{References}

Bergala, Alain. 2004. Abbas Kiarostami. Paris: Éditions Cahiers du Cinéma.

Grønstad, Asbjørn. 2013. Abbas Kiarostami's Shirin and the Aesthetics of Ethical Intimacy. Film Criticism vol. 37, no. 2 (Winter 2012/2013): 22-37.

Király, Hajnal. 2010. Abbas Kiarostami and a New Wave of the Spectator. Acta Universitatis Sapientiae. Film and Media Studies. Vol 3: 133-142. http://www. acta.sapientia.ro/acta-film/C3/film3-9.pdf. Last accessed 12. 01. 2016.

Lacan, Jacques. 1978. The Four Fundamental Concepts of Psychoanalysis. The Seminar of Jacques Lacan. Book XI. New York, London: W.W. Norton \& Company.

Levesque, Simon. 2013. Indéterminations narratives dans Copie conforme d'Abbas Kiarostami. Une critique des théories dualistes du signe considérées d'après la faculté de juger. [Narrative Indeterminations in Abbas Kiarostami's Certified Copy. A Critique of Dualist Theories of Signe, Considered Based on the Faculty of Judgement.] Cygne noir no 1. http://www.revuecygnenoir. org/numero/article/indeterminations-narratives-dans-copie-conformekiarostami>. Last accessed 30. 06. 2016.

McGowan, Todd. 2007. The Real Gaze. Film Theory after Lacan. Albany: State University of New York Press.

Merleau-Ponty, Maurice, 2002 [1945]. Phenomenology of Perception. Translated by Smith, Colin. London: Routledge Classics.

Merleau-Ponty, Maurice. 1964. Le visible et l'invisible. [The Visible and the Invisible.] Paris: Éditions Gallimard.

Mulvey, Laura 2006. Death $24 x$ a Second. Stillness and the Moving Image. London: Reaktion Books.

Nancy, Jean-Luc. 2001. L'Évidence du film. Abbas Kiarostami. [The Evidence of Film: Abbas Kiarostami.] Bruxelles: Yves Gevaert Éditeur.

Sabouraud, Frédéric. 2010. Abbas Kiarostami. Le cinéma revisité. [Abbas Kiarostami. Cinema Revisited.] Rennes: Presses Universitaires de Rennes.

Sartre, Jean-Paul. 1978. Being and Nothingness. An Essay on Phenomenological Ontology. New York: Pocket Books.

Shams, Sussan. 2011. Le cinéma d'Abbas Kiarostami. Un voyage vers l'Orient mystique. [The Cinema of Abbas Kiarostami. A Travel to the Mystique East.] Paris: L'Harmattan.

Sontag, Susan 2005. On Photography. New York: Rosetta Books. 


\section{List of Figures}

Figure 1. Abbas Kiarostami: Homework (1989). The cinematic apparatus is made visible.

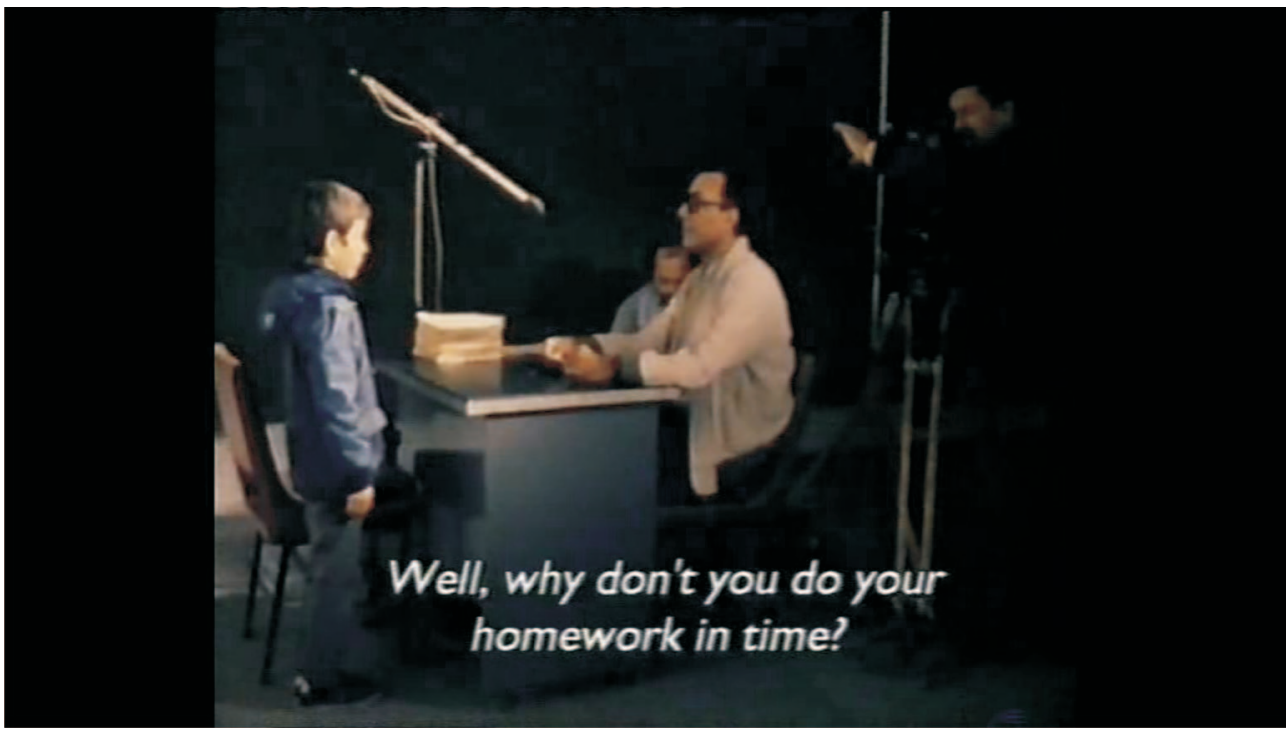

Figure 2. Abbas Kiarostami: Certified Copy (2010). Binoche fixes her hair using the lens of the camera as mirror.

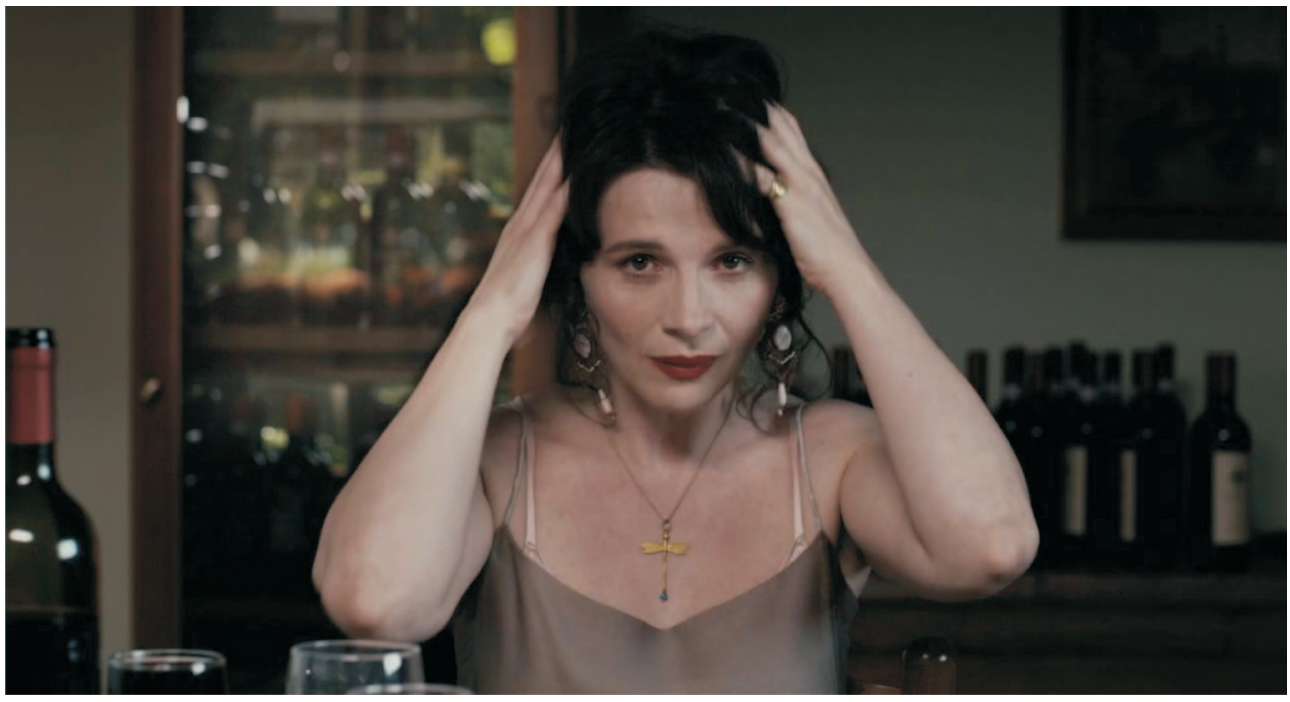


Figure 3. Abbas Kiarostami: Through the Olive Trees (1994). "The gaze of the tombstone" - Hossein arrives to the cemetery.

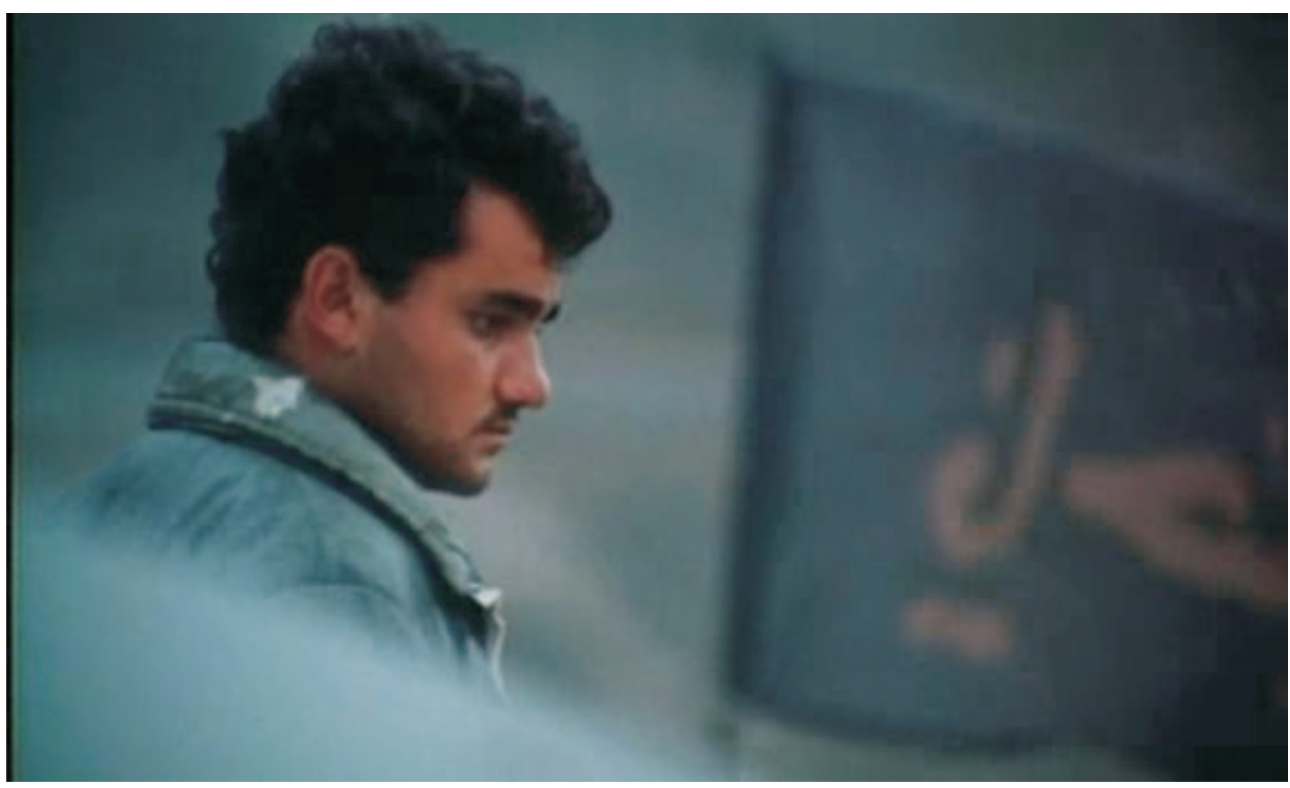

